\title{
Anticonvulsant activity of bioflavonoid gossypin
}

\author{
Duraisami Rasilingam¹, Srinivasan Duraisamy² and Ramaswamy Subramanian3 \\ ${ }^{1}$ Department of Pharmacognosy, Nandha College of Pharmacy, Koorapalayam Pirivu, Perundurai Main Road, \\ Erode 638 052, Tamil Nadu, India; ${ }^{2}$ Department of Pharmacology, Raja Muthiah Dental Collge, Annamalai Uni- \\ versituy, Annamalai Nagar, Chidambaram 608 002. Tamil Nadu, India; ${ }^{3}$ Department of Pharmacology, Arupadai
}

\begin{tabular}{|c|c|}
\hline \multicolumn{2}{|l|}{ Article Info } \\
\hline Received: & $1 \mathrm{Se}$ \\
\hline Accepted: & 10 \\
\hline Available Online: & 17 September 2008 \\
\hline \multicolumn{2}{|c|}{ DOI: $10.3329 /$ bjp.v4i1.1081 } \\
\hline \multicolumn{2}{|c|}{$\begin{array}{l}\text { Cite this article: } \\
\text { Rasilingam D, Duraisamy S, Subra- } \\
\text { manian R. Anticonvulsant activity of } \\
\text { bioflavonoid gossypin. Bangladesh J } \\
\text { Pharmacol. 2009; } 4: 51-54 \text {. }\end{array}$} \\
\hline
\end{tabular}

\begin{abstract}
The anticonvulsant activity of gossypin was investigated by studying the effects on seizures induced by pentelentetrazole, strychnine and maximal electroshock convulsive methods in mice. Gossypin (10 and $20 \mathrm{mg} / \mathrm{kg}$ ) significantly reduced the duration of convulsion in tonic seizure induced by pentelenetetrazole (95 mg/kg, intraperitoneally). Gossypin (20 mg/kg p.o) significantly reduced the tonic extensor convulsion induced by strychnine and maximum electroshock-induced convulsions. The data obtained suggest that gossypin have anticonvulsant property and may probably be affecting
\end{abstract}

\section{Introduction}

Epilepsy is a neurological disorder that affects a wide range of people throughout the world. It is a disorder of brain characterize by unpredictable and periodic occurrence of a transient alteration of behavior due to the disordered, synchronous and rhythmic firing of populations of brain neurons (McNamara, 2001). Incidence of epilepsy in developed countries is approximately 50 per 100,000 while that of developing country is 100 per 100,000 (WHO, 2006). It has been observed that the presently available antiepileptic drugs are unable to control seizures effectively in as many as $25 \%$ of the patients (Mattson, 1992). The conventional antiepileptic agents like phenytoin, carbamazeipine and sodium valporate carry with them several serious side effects notably neurotoxicity (Gupta and Malhotra, 1997). As majority of antiepileptic drugs are consumed life long, concomitant administration of other drugs predisposes to the risk of drug interaction. However, newer antiepileptics like gabapentin, vigabatrin, lamotrigine, etc are used supplemental to the conventional agents (McNamara, 2001). Thus, it is necessary to investigate for an antiepileptic agent that is highly effica- cious as well as safe in items of drug related toxicity. The aim of treating an epileptic is not only to abolish the occurrence of seizures but also to lead a self sustained life.

Gossypin is a bioflavanoid (gossypin-8-0 glucoside; 3,5,7,3,4-pentahydroxy-8-0-glucosylflavone), which is naturally occurring in various plants belonging to the family of Malvaceae (Vidyasagar et al., 2008).

Flavonoids are polyphenolic compounds that occur ubiquitously in foods of plant origin. Over 4000 different naturally occurring flavonoids have been described. The flavonoids show various biological activities including anti-oxidant, anti-inflammatory activity, activity on coronary heart diseases and cytotoxicantitumor activity (Babu et al., 2003). However, the anxiolytic properties of these flavonoids have been rarely investigated. Previously, the anxiolytic-like effects of simple flavone, chrysin (5,7-dihydroyflovone) have been reported, which behaves as a competitive ligand of the benzodiazepine receptors (Wolfman et al., 1994). Apigenin has been reported to show similar activity in mice with only slight sedative effect (Viola et al., 1995). 


\section{Materials and Methods \\ Drugs and chemicals \\ Gossypin was purchased from Sigma Chemical Com- pany (USA). All other chemicals used were in analytical grade.}

\begin{abstract}
Animals
Albino mice weighing between 18-22 g were used. The animals were obtained from animal house, IRT Medical College, Perundurai, Erode. They were placed at random and allocated to treatment groups in polypropylene cages with paddy husk as bedding. Animals were housed at a temperature of $24 \pm 2{ }^{\circ} \mathrm{C}$ and relative humidity of $30-70 \%$. A 12:12 light:day cycle was followed. All animals were allowed to free access to water and fed with standard commercial pelleted rat/mice chaw (M/S. Hindustan Lever Ltd, Mumbai). All the experimental procedures and protocols used in this study were reviewed by the Institutional Animal Ethics Committee (IAEC) and were in accordance with the guidelines of the IAEC.
\end{abstract}

Pentelenetetrazole- or strychnine-induced seizure model

In each type of seizure model, the mice were divided into five groups with six animals. Group I served as solvent control, received $0.9 \% \mathrm{w} / \mathrm{v}$ of saline $(1 \mathrm{~mL} / \mathrm{kg})$, Group II received diazepam $(1 \mathrm{mg} / \mathrm{kg})$, treated as positive control and Group III, IV and $\mathrm{V}$ received gossypin 5, 10 and $20 \mathrm{mg} / \mathrm{kg}$ respectively. All the drugs were administered by orally $30 \mathrm{~min}$ prior to the administration of pentelenetetrazole $(6 \mathrm{mg} / \mathrm{kg})$ by subcutaneous route or strychnine $(2 \mathrm{mg} / \mathrm{kg})$ by intramuscular injection. The animals were observed for 1 hour by placing in a separate cage. The duration of seizures (tonic-clonic convulsions) were recorded (Yemitan and Salahdeen, 2005; Salahdeen and Yemiten, 2006).

\section{Maximum electroshock-induced seizure model}

The mice were divided into five groups with six animals in each. Group I served as solvent control, received $0.9 \% \mathrm{w} / \mathrm{v}$ of saline $(1 \mathrm{~mL} / \mathrm{kg})$, Group II received diazepam $(1 \mathrm{mg} / \mathrm{kg})$, treated as positive control and Group III, IV and V received gossypin 5, 10 and $20 \mathrm{mg} /$ $\mathrm{kg}$ respectively. All the drugs were administered orally $60 \mathrm{~min}$ prior to the electroshock. The electroshock induced in animal by passing a current of $45 \mathrm{~mA}$ for 0.2 sec duration through electroconvulsiometer (Techno, India) using corneal electrodes. The incidence and duration of extensor tonus were noted. The duration of seizures (tonic-clonic convulsions) was recorded (Achliya et al., 2005).

\section{Statistical analysis}

The values were expressed as mean \pm SEM. The statistical analysis was carried out by one-way analysis of variance (ANOVA) followed by Dunnet's ' $t$ ' test. $P$ values $<0.05$ were considered significant.

\section{Results and Discussion}

In pentelenetetrazole-induced seizure model, gossypin 10 and $20 \mathrm{mg} / \mathrm{kg}$ produced significant $(\mathrm{p}<0.01)$ reduction in duration of convulsion and was comparable to that produced by diazepam (Figure 1). In strychnineinduced seizures model, gossypin $20 \mathrm{mg} / \mathrm{kg}$ and diazepam showed significant $(\mathrm{p}<0.01)$ reduction in duration of convulsion, but gossypin 5 and $10 \mathrm{mg} / \mathrm{kg}$ did not exhibit anticonvulsant effect. In the maximum electroshock induced seizure model, gossypin $20 \mathrm{mg} /$ $\mathrm{kg}$ and diazepam showed significant $(\mathrm{p}<0.01)$ reduction in duration of convulsion, but gossypin 5 and $10 \mathrm{mg} /$ $\mathrm{kg}$ did not exhibit anticonvulsant effect.

The anticonvulsant activity of gossypin at various dose levels viz, 5, 10 and $20 \mathrm{mg} / \mathrm{kg}$ p.o. were studied by the pentelenetetrazole-, strychnine- and maximum electroshock-induced seizure models. The most popular and widely used animal seizure models are the traditional maximum electroshock-induced seizure and pentalenetetrazole tests. Prevention of seizures induced by pentelenetetrazole in laboratory animals is the most commonly used preliminary screening test for characterizing potential anticonvulsant drugs. The maximum electroshock-induced seizure test is considered to be a predictor of likely therapeutic efficacy against generalized tonic-clonic seizures. By contrast, the pentalenetetrazole test represents a valid model for human generalized myoclonic and also absence seizures. Other chemoconvulsant models for primary generalized seizures include by bicuculine $\left(\mathrm{GABA}_{\mathrm{A}}\right.$ receptor antagonized), strychnine (glycine receptor antagonist) and aminophylline (adenosine-receptor antagonist). The pentelenetetrazole assay has been used primarily to evaluate antiepileptic drugs. However, it has been shown that, most anxiolytic agents are also able to prevent or antagonize metrazole-induced convulsion. Generally, compounds with anticonvulsant activity in the petitmal epilepsy are effective in pentelenetetrazole -induced seizure model (Loscher and Schmidt, 1988).

Data from the study showed that the tonic convulsion produced by pentelenetetrazole was significantly delayed by gossypin. The data also show that diazepam antagonize the pentelenetetrazole-induced convulsion. According to be Sarro et al. pentelenetetrazole may be exerting its convulsive effect by inhibiting the activity of gamma amino butyric acid (GABA) at GABAA receptors (De Sarro et al., 1999) the major inhibitory neurotransmitter which is implicated in epilepsy. The enhancement and inhibition of the neurotransmission of GABA will attenuate and enhance convulsion 


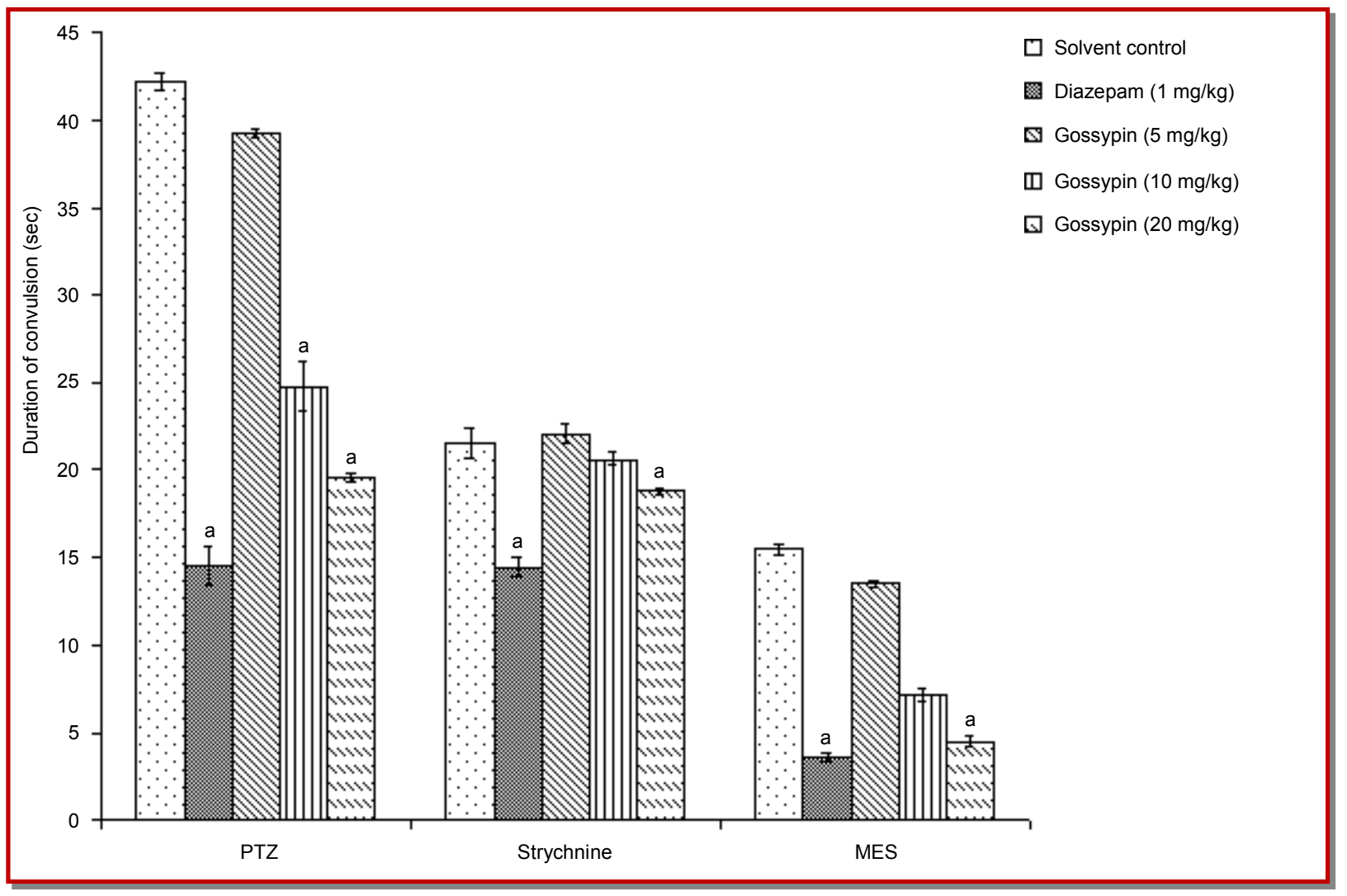

Figure 1: Anticonvulsant activity of gossypin on pentelenetetrazole- (PTZ), strychnine- and maximal electroshock (MES)-induced seizure in mice. Values were expressed as mean \pm SEM $(n=6)$; a $<<0.01$ vs solvent control

respectively (Meldrum, 1981; Gale, 1992; Westmorland et al., 1994). Phenobarbitone and diazepam have been shown to exert their antiepileptic effects by enhancing the GABA-mediated inhibition in the brain (Porter and Meldrum, 2001). It is possible that diazepam and gossypin antagonize pentelenetetrazole convulsion in this study by enhancing GABA neurotransmission. Since the gossypin delayed the occurrence of pentalenetetrazole-induced convulsion, it is probable that it may be interfering with GABA aminergic mechanism(s) to exert its anticonvulsant effect.

On the other hand, in the strychnine-induced seizure model the gossypin 5, 10 and $20 \mathrm{mg} / \mathrm{kg}$ administrated. p.o. The effects were observed that significant reduction in the duration of convulsion effect only when used in the higher dose of gossypin which it is compared with diazepam $1 \mathrm{mg} / \mathrm{kg}$.

In the strychnine-induced seizure model, it is known that strychnine directly antagonize the inhibitory spinal reflexes of glycine (Sayin et al., 1993). The suppression of seizure by gossypin $20 \mathrm{mg} / \mathrm{kg}$, may be due to, the glycine inhibitory mechanisms.

The maximal electroshock test is the most widely used animal model in antiepileptic drug discovery, because seizure induction is simple and the predictive value for detecting clinically effective antiepileptic is high (White, 1995; Loscher, 1999). The maximal electroshock test identifies agents with activity against generalized tonic clonic seizures (White, 1995) using clinically established antiepileptic drugs. The pharmacology of acute maximal electroshock dose not differs from the pharmacology of generalized tonic-clonic seizures in genetic models with choronic epilepsy, eg. audiogenicseizure susceptible mice and rats or epileptic gerbils (Loscher, 1999). In addition to identifying drug activity against generalized tonic-clonic seizures, it has often been proposed that the maximal electroshock test predicts anticonvulsant drug effects against partial seizures. The anticonvulsant activity of gossypin $20 \mathrm{mg} /$ $\mathrm{kg}$, in maximal electroshock model indicates that gossypin might precipitate the tonic and clonic seizures.

From the above study, it was concluded that, the gossypin a bio-flavonoid exhibits anticonvulsant activity and the probable mode of action may be due to GABAaminergic mediation, glycine inhibitory mechanism and inhibit the electrical kindling effect.

\section{References}

Achliya GS, Wadodkar SG, Darle AK. Evaluation of CNS 
activity of Bramhi Ghrita. Indian J Pharmacol. 2005; 37: 3336.

Babu BH, Jayaram HN, Nair MG, Ajaykumar KB, Padikkala J. Free radical scavenging, antitumor and anti-carcinogenic activity of gossypin. J Exp Clin Cancer Res. 2003; 6: 2281-89.

De Sarro A, Cecchetti V, Fravolini V, Naccari F, Tabarrini O, De Sarro G. Effects of novel $\beta$-desfluroquinolones and classic quinolones on pentelenetetrazole-induced seizures in mice. Antimicrob Agents Chemother. 1999; 43: 1729-36.

Gale MK. GABA and epilepsy basic concepts from preclinical research. Epilepsia 1992; 33 Suppl: S3-12.

Gupta YK, Malhotra J. Adenosinergic system as an endogenous anticonvulsant mechanism. J Physiol Pharmacol. 1997; 41: 329-43.

Loscher W, Schmidt D. Which animal models should be used in the search for new antiepileptic drugs? A proposal based on experimental and clinical considerations. Epilepsy Res. 1988; 2: 145-81.

Mattson RH. Drug treatment of partial epilepsy. Adv Neurol. 1992; 57: 643-50.

Meldrum BS. GABA agonists as antiepileptic agents. Adv Biochem Psycopharmacol. 1981; 26: 207-17.

McNamara JO. Drugs effective in the therapy of the epilepsies. In: Goodman and Gillman's The pharmacological basis of therapeutics. Hardman, JG, Limbird LE (eds). 10 th ed. New York, McGraw-Hill, 2001, pp 521-39.

Porter RJ, Meldrum BS. Antiseizure drugs. In: Basic and clinical pharmacology. Katzung BG (ed). New York, Lange Medical Books/McGraw-Hill, 2001, pp 403-17.

Salahdeen HM, Yemitan OK. Neuropharmacological effects of aqueous leaf extract of Bryophyllum pinnatum in mice.
African J Bio Med Res. 2006; 9: 101-07.

Sayin U, Cengiz S, Altug T. Vigabatin as an anticonvulsant against penteletetrazole seizures. Pharmacol Res. 1993; 28: 325-31.

Vidyasagar J, Srinivas M, Nagulu M, Venkatasam A, Udyakiran B, Krishna DR. Protein binding study of gossypin by equilibrium dialysis. Curr Trends Biotech Phar. 2008; 2: 396401.

Viola H, Wasowski C, Levidestein M, Wolfmane, Silveria R, Dajas F, Medina JH, Paladini AC. Apigenin, a componant of Marlicaria recutita flowers, is a central benzodiazepine receptors-legand with anxiolytic effects. Planta Med. 1995; 61: 213-16.

Westmoreland BF, Benarroch EE, Dube JR, Regan TJ, Sandok BA. Medical neurosciences. Mayo Foundation Rochester, 1994, pp 307-12.

White HS. Clinical significance of animal seizure models and mechanism of action, studies of potential antiepileptic drugs. Epilepsia 1995; 38 Suppl: S9-17.

WHO. Epilepsy: Etiology, epidemiology and prognosis. www.who.int/entire/mediacentre/factsheets/fs165/en/25k-16jan2006.

Wolfman C, Viola H, Paladini A, Dajas F, Media JH. Possible anxiolytic effects of chrysin, a central benzodiazepine receptor ligand isolated from Passifloara coerulea. Pharmacol Biochem Behav. 1994; 47: 1-4.

Yemitan OK, Adeymi OO. CNS depressant activity of Lecaniodisurs cupanioides. Fitoterpia 2005; 76: 412-18.

Yemitan OK, Salahdeen HM. Neurosedative and muscle relaxant activities of aqueous extract of Bryophyllum pinnatum. Fitoterpia 2005; 76: 187-93. 